\title{
The study of the fertilizing effect of wheat straw ash in a greenhouse experiment
}

\author{
Rita Kremper - Réka Hidvégi - Andrea Balláné Kovács - Jakab Loch \\ University of Debrecen Faculty of Agricultural and Food Sciences and Environmental Management, \\ Department of Agricultural Chemistry and Soil Science, Debrecen, Hungary \\ kremper@agr.unideb.hu
}

\section{SUMMARY}

\begin{abstract}
The effect of wheat straw ash as a fertlizizer was studied in a pot experiment with an acidic sandy loam soil $\left(p H_{K C l}=4.9\right)$ with weak $K$ and $P$ supply. The test plant was ryegrass (Lolium perenne). The treatments were the following: 1. control untreated soil, 2. NPK fertilizer, 3. small dose of ash $\left(1.4 \mathrm{~g} \mathrm{~kg}^{-1}\right)$, 4 large dose of ash $\left(2.8 \mathrm{~g} \mathrm{~kg}^{-1}\right)$, 5. small dose ash completed with NP fertilizers. Soil parameters $\left(\mathrm{pH} \mathrm{H}_{2} \mathrm{O}\right.$, $\mathrm{pH} \mathrm{KCl}_{\mathrm{K}}$, ammoinum-lactate soluble $\mathrm{P}, \mathrm{K}, 0.01 \mathrm{M} \mathrm{CaCl}_{2}$ soluble $\mathrm{PO}_{4}{ }^{3-}-\mathrm{P}, \mathrm{K}, \mathrm{Mn}, \mathrm{Cu}, \mathrm{Zn}$ ) and plant parameters (yield, $\mathrm{P}, \mathrm{K}, \mathrm{Ca}, \mathrm{Mg}, \mathrm{Zn}, \mathrm{Mn}$ uptake) were investigated. Based on the analysis of the straw ash sample and the results of pot experiment it can be stated that the wheat straw ash is suitable for the fertilization of the studied soil. The small dose ash completed with NP resulted in the largest yield increment (43\%). In order of the treatments the $\mathrm{pH}_{\mathrm{KCl}}$ changes to: 4.9, 4.8, 5.2, 5.8, 5.1. As the $\mathrm{N}: \mathrm{P}_{2} \mathrm{O}_{5}: \mathrm{K}_{2} \mathrm{O}$ ratio is $0: 1: 3.5$ in the wheat straw ash sample, to reach optimal yield ash should be completed with $N$ and $P$.
\end{abstract}

Keywords: wheat straw, ash, fertilization

\section{ÖSSZEFOGLALASS}

Dolgozatunkban gabonaszalma hamu hatását vizsgáltuk tenyészedény kísérletben savanyú, homokos vályog talajon $\left(p H_{K C l}=4,9\right)$, melynek Kés P ellátottsága gyenge volt. A tesztnövény angolperje volt (Lolium perenne). A következö kezeléseket alkalmaztuk: 1. kontroll 2. NPK oldatok 3. kis adag hamu $(1.4 \mathrm{~g} / \mathrm{kg}) ; 4$. nagy adag hamu $(2,8 \mathrm{~g} / \mathrm{kg}) 5 . \mathrm{kis}$ adag hamu NP kiegészitéssel. Kísérletünkben az alábbi talaj paraméterek változását vizsgáltuk ( $\mathrm{pH}_{\mathrm{H}_{2} \mathrm{O}}, \mathrm{pH}_{\mathrm{KCl}}$, ammónium-laktát oldható - $\mathrm{P},-\mathrm{K}, 0,01 \mathrm{M} \mathrm{CaCl}_{2}$ oldható $\mathrm{PO}_{4}{ }^{3-}-\mathrm{P}, \mathrm{K}, \mathrm{Mn}, \mathrm{Cu}, \mathrm{Zn}$ ), valamint a tesztnövény termését, $P, K, C a, M g, Z n, M n$-tartalmát és-felvételét. A hamu vizsgálatok, illetve a tenyészedényes kísérlet eredményei alapján kijelenthetjük, hogy a gabonaszalma hamu minta alkalmas a vizsgált talaj trágyázására. Az NP-vel kiegészitett kis adag hamu kezelés esetén tapasztaltuk a legnagyobb termésnövekedést (43\%-os). A kezelések sorrendjében a talajok $\mathrm{pH}_{K C l}$ értékei a következöképpen változtak: 4,9; 4,8; 5,2; 5,8; 5,1. Mivel a hamu minta $\mathrm{N}: \mathrm{P}_{2} \mathrm{O}_{5}: K_{2} \mathrm{O}$ aránya $0: 1: 3,5$; az optimális termések eléréséhez a hamuminta NP kiegészitése szükséges.

Kulcsszavak: gabonaszalma, hamu, mütrágyázás

\section{INTRODUCTION}

One of the biggest challenges of sustainable agriculture is to minimize the use of chemicals and to maintain an appropriate yield at the same time. Since 1989 the quantity of organic manure has strongly decreased in Hungary, due to the drastic reduction of the livestock number (Árendás et al., 2005). Therefore most of the agricultural plant by products (e.g. straws) can not be used as bedding materials of manure, it is rather applied as energy source. One part of the current renewable energy in Hungary is from the combustion of biomass. A large proportion $(57 \%)$ is from wood, while another part comes from other plant by-products. Thus a large amount of ash is produced by both power plants and rural population. Currently the disposal of ash is an environmental problem in Hungary. The use of ashes as fertilizer could be a solution of this problem and it could decrease the consumption of commercial fertilizers as well.

The bulk of the elements in ashes are: $\mathrm{K}, \mathrm{Ca}, \mathrm{Mg}$, $\mathrm{Na}, \mathrm{P}, \mathrm{S}, \mathrm{Si}$ and $\mathrm{Cl}$, which are essential for plants. In addition ashes contain minor amounts of micronutrients (Fe, Mn, Cu, Zn, Mo, B (Mengel and Kirkby, 1987) that can be toxic in excess and other toxic elements such as $\mathrm{Cd}$ and $\mathrm{Pb}$, which presence are undesirable. In case of a complete combustion the organic content of the plant is lost and only the mineral part remained. In the heating plants and domestic farm furnaces the combustion is not complete, thus ashes from them can contain some charcoal, but they are nearly free from nitrogen (Schiemenz et al., 2010).

The elements in ashes are present in the form of silicates, oxides, carbonates, sulfates, chlorides, phosphates etc. The dominant components in ashes of wheat are $\mathrm{SiO}_{2}, \mathrm{~K}_{2} \mathrm{O}$ and $\mathrm{CaO}$ (Ivarsson and Nilsson, 1988), therefore it has an alkalizing effect.

The main factor that determines the ash composition is the plant species and plant parts from which it is made. Among plant species considerable differences in mineral content occur which are genetically fixed. (Mengel and Kirkby, 1987). Beyond it the composition of wheat straw ash is also dependent on the cultivar (Safdar et al., 2009), the soil nutrient supply, climatic conditions (Yasin et al., 2010) and the combustion process (Sander and Andre'n, 1997; Stankowski et al., 2012).

There are several recommendations for the amount of ash that can be used as a fertilizer. In Sweden for wood ash the maximum amount is $3 \mathrm{tha}^{-1} 10$ years $^{-1}$ The practise in Finland applies $3-5 \mathrm{t} \mathrm{ha}^{-1}$ wood ash when ash is applied in peat soils. In Denmark it ranges from $0.5-7.5$ t ha $^{-1} 10$ year ${ }^{-1}$ depending on the $\mathrm{Cd}$ concentration of wood ash (Röser et al., 2008). Sander and Andre'n (1997) examined several straw ash types from seven heating plants and stated that $1-2$ tones straw ash ha-1 could be returned to the field at intervals of 5-10 years. As loose ash is difficult to handle, some processing methods (grinding, palletizing, and granulating) is recommended (Rotheneder et al., 2005) before application. 
Our experiment is based on an actual ash disposal problem in a Hungarian village. The aim of our work is to examine whether the wheat straw ash formed in the village is suitable for local fertilization. We set a greenhouse experiment to study the effect of wheat straw ash on the yield and the element content of ryegrass and the soil parameters. In case of positive response we suggest an ash dose per hectare which is to be tested in a field experiment.

\section{MATERIAL AND METHODS}

\section{Soil, ash}

In 2015 a pot experiment was conducted with the aim of studying the application of wheat straw ash as a fertilizer. The meadow soil used for the experiment was taken from Magyarhomorog (Hungary), the ash sample is originated from the same village. As the population of the village has used plant biomass for heating, a large amount of ash has generated which disposal is not dissolved. Some characteristics of the soil can be seen in Table 1 .

The soil has sandy loam texture (10.2\% clay, $26.7 \%$ silt, $63.5 \%$ sand). The $\mathrm{K}$ and $\mathrm{P}$ status of the soils were characterized from ammonium lactate (AL) solution according to the Hungarian Standard (MSZ 20135) and $0.01 \mathrm{M} \mathrm{CaCl}_{2}$ solution (Houba et al., 1990). The $\mathrm{CaCl}_{2}-\mathrm{K}, \mathrm{PO}_{4}^{3-}-\mathrm{P}$ values describe the amount of the readily available $\mathrm{K}$ and orthophosphate-P forms, while AL-K,P values characterizes some part of the nutrient reserves as well. The applied soil had poor fertility. It was acidic and the $\mathrm{K}$ and $\mathrm{P}$ supply were weak. This evaluation is given regarding to the AL values according to the Hungarian recommendation system (Buzás et al., 1979 ).

The ash sample is made from wheat straw in a traditional domestic co-fired boiler. After digestion with $\mathrm{HNO}_{3}-\mathrm{H}_{2} \mathrm{O}_{2}$ (MSZ 21470-50:1998) the Ca, $\mathrm{Mg}$, $\mathrm{Fe}, \mathrm{Mn}, \mathrm{Cd}, \mathrm{Cr}, \mathrm{Cu}, \mathrm{Ni}, \mathrm{Pb}$ and $\mathrm{Zn}$ content of the ash was determined with ICP-AES spectrometer. Regarding to $\mathrm{K}$ and $\mathrm{P}$ we determined the AL soluble $\mathrm{K}$ and $\mathrm{P}$ content of the ash to characterize the plant available nutrient contents.

\section{Treatments, analysis}

Pots were filled with $1 \mathrm{~kg}$ air dry soils. The ash and fertilizer were mixed into the soil in solid and liquid form respectively. Table 2 summarizes the applied treatments.

The NPK treatment represents the optimal NPK dose. The amount of ash in case of ASH1 treatment was determined based on the AL-K content of the ash. The nitrogen vas added as $\mathrm{NH}_{4} \mathrm{NO}_{3}$, the phosphorous as $\mathrm{Ca}\left(\mathrm{H}_{2} \mathrm{PO}_{4}\right)_{2}$ and the potassium as $\mathrm{KCl}$ solution. Soils were kept at constant moisture by daily irrigation, which was $65 \%$ water capacity of the soils. The experimental plant was ryegrass (Lolium perenne L.). $1 \mathrm{~g}$ seeds were sown in the soils per pots. All treatments were replicated four times. The ryegrass was cut 5 weeks after sowing (June $26^{\text {th }}$ ).

After the experiment the following soil and plant parameters were measured and calculated: $\mathrm{pH}_{\mathrm{H}_{2} \mathrm{O}}$, $\mathrm{pH}_{\mathrm{KCl}}$, AL soluble $\mathrm{P}, \mathrm{K}, 0.01 \mathrm{M} \mathrm{CaCl}_{2}$ soluble $\mathrm{PO}_{4}^{3-}$ $\mathrm{P}, \mathrm{K}, \mathrm{Mn}, \mathrm{Cu}, \mathrm{Zn}$ and yield, $\mathrm{P}, \mathrm{K}, \mathrm{Ca}, \mathrm{Mg}, \mathrm{Zn}, \mathrm{Mn}$ content amd uptake respectively). The element uptake was calculated from the dry matter production and the element content. The plant $\mathrm{P}$ content was determined from the $\mathrm{H}_{2} \mathrm{SO}_{4}-\mathrm{H}_{2} \mathrm{O}_{2}$ digestion with ammonium molybdenate vanadate UV/VIS spectrophotometry method (Thammné et al., 1968). Plant K content was measured from $\mathrm{H}_{2} \mathrm{SO}_{4}-\mathrm{H}_{2} \mathrm{O}_{2}$ digestion with flame photometer (UNICAM SP95B) and the plant $\mathrm{Ca}, \mathrm{Mg}$, $\mathrm{Zn}, \mathrm{Mn}$ content were measured from $\mathrm{HNO}_{3}-\mathrm{H}_{2} \mathrm{O}_{2}$ digestion by FAAS technique (Varian Spectr. AA-20). Soil and plant data were subjected to one way variance analysis (SPSS). The means of the data were compared by Tuckey post hoc test at $0.05 \%$ significance level

\section{RESULTS AND DISCUSSION}

The composition of the wheat straw ash is presented in Table 3. As $\mathrm{Ca}$ and $\mathrm{Mg}$ contents are $3.8 \%$ and $1.5 \%$ respectively, ash can contribute to $\mathrm{Ca}$ and $\mathrm{Mg}$ supply. The presence of $\mathrm{Fe}, \mathrm{Mn}, \mathrm{Cu}$ and $\mathrm{Zn}$ in ash as microelements is also important.

Soil properties at the beginning of the pot experiments

\begin{tabular}{|c|c|c|c|c|c|c|c|}
\hline $\begin{array}{l}\mathrm{pH} \\
\mathrm{H}_{2} \mathrm{O}\end{array}$ & $\begin{array}{c}\mathrm{pH} \\
\mathrm{KCl}\end{array}$ & $\begin{array}{c}\text { AL-K } \\
\left(\mathrm{mg} \mathrm{kg}^{-1}\right)\end{array}$ & $\begin{array}{c}\text { AL-P } \\
\left(\mathrm{mg} \mathrm{kg}^{-1}\right)\end{array}$ & $\begin{array}{l}\mathrm{CaCl}_{2}-\mathrm{K} \\
\left(\mathrm{mg} \mathrm{kg}^{-1}\right)\end{array}$ & $\begin{array}{c}\mathrm{CaCl}_{2}-\mathrm{PO}_{4}{ }^{3-}-\mathrm{P} \\
\left(\mathrm{mg} \mathrm{kg}^{-1}\right)\end{array}$ & $\begin{array}{l}\mathrm{CaCl}_{2}-\mathrm{Mg} \\
\left(\mathrm{mg} \mathrm{kg}^{-1}\right)\end{array}$ & $\begin{array}{l}\mathrm{CaCl}_{2}-\mathrm{Mn} \\
\left(\mathrm{mg} \mathrm{kg}^{-1}\right)\end{array}$ \\
\hline 5.93 & 4.90 & 112.5 & 22.7 & 49.9 & 0.35 & 247 & 18 \\
\hline
\end{tabular}

Treatments of the pot experiments and the amount of nutrients given

\begin{tabular}{|c|c|c|c|c|c|c|c|c|}
\hline \multirow{2}{*}{ Treatments } & \multirow{2}{*}{ Abbr. } & \multicolumn{3}{|c|}{ NPK dose $\left(\mathrm{mg} \mathrm{pot}^{-1}\right)$} & \multirow{2}{*}{ Ash dose $\left(\mathrm{g}_{\mathrm{pot}}{ }^{-1}\right)$} & \multicolumn{3}{|c|}{ Nutrient amounts } \\
\hline & & $\mathrm{N}$ & $\mathrm{P}$ & $\mathrm{K}$ & & $\mathrm{N}$ & $\mathrm{P}$ & $\mathrm{K}$ \\
\hline Control & $\mathrm{CON}$ & - & - & - & - & - & - & - \\
\hline NPK & NPK & 100 & 35 & 99 & - & 100 & 35 & 99 \\
\hline Ash small dose & ASH1 & - & - & - & 1.4 & & 15 & 99 \\
\hline Ash higher dose & ASH2 & - & - & - & 2.8 & & 30 & 99 \\
\hline Ash small dose+NP & $\mathrm{ASH} 1+\mathrm{NP}$ & 100 & 20 & - & 1.4 & 100 & 35 & 99 \\
\hline
\end{tabular}

Note: nutrient amount of ashes was determined regarding to AL-K and AL-P. 
Metal content of the ash sample

\begin{tabular}{|c|c|c|c|c|c|c|c|c|c|c|}
\hline & $\mathrm{Ca}$ & $\mathrm{Mg}$ & $\mathrm{Fe}$ & $\mathrm{Mn}$ & $\mathrm{Cd}$ & $\mathrm{Cr}$ & $\mathrm{Cu}$ & $\mathrm{Ni}$ & $\mathrm{Pb}$ & $\mathrm{Zn}$ \\
\hline $\begin{array}{l}\text { Metal content of ash } \\
\left(\mathrm{mg} \mathrm{kg}^{-1}\right)\end{array}$ & 38838 & 15259 & 2058 & 183 & 0.67 & 7.06 & 47.3 & 6.54 & 8.4 & 98.2 \\
\hline $\begin{array}{l}\text { Quantity in } 1 \mathrm{t} \text { ash } \\
(\mathrm{kg})\end{array}$ & 38.8 & 15.3 & 2.05 & 0.183 & 0.00067 & 0.00706 & 0.047 & 0.00654 & 0.0084 & 0.098 \\
\hline $\begin{array}{l}\text { Maximum allowed quantity* } \\
\left(\mathrm{kg} \mathrm{ha}^{-1} \mathrm{year}^{-1}\right)\end{array}$ & - & - & - & - & 0.15 & 10 & 10 & 2 & 10 & 30 \\
\hline
\end{tabular}

Note: *50/2001. Hungarian Government Regulation for the maximum allowed quantity of harmful metals that can be spread with wastewater, sewage sludge or sewage sludge compost on agricultural area.

From the element content it can be calculated that with 1 ton of wheat ash we put $2 \mathrm{~kg} \mathrm{Fe}, 0.18 \mathrm{~kg} \mathrm{Mn}$, $0.05 \mathrm{~kg} \mathrm{Cu}$ and $0.10 \mathrm{~kg} \mathrm{Zn}$ into the soil. Similarly related to toxic $\mathrm{Cd}$ and $\mathrm{Pb}$ with $1 \mathrm{t}$ of ash the load is $0.67 \mathrm{~g} \mathrm{Cd}$ and $8.4 \mathrm{~g} \mathrm{~Pb}$. These amounts are far less than that is allowed according to the 50/2001. Hungarian Government Regulation. Besides ash has an alkalizing effect, which decreases the $\mathrm{Cd}$ availability. Ochecova (2013) added woodash with $3.09 \mathrm{mg} \mathrm{kg}^{-1} \mathrm{Cd}$ content to acidic Fluvisol and Cambisol soil in three subsequent years in a pot experiment. She observed that the wheat $\mathrm{Cd}$ content declined with increasing ash doses due to its alkalizing effect. Thus application of ash has got a low risk of $\mathrm{Cd}$ contamination.

The AL-P and AL-K content of the ash were the following: $\mathrm{AL}-\mathrm{P}=10.6 \mathrm{~g} \mathrm{~kg}^{-1}$ and $\mathrm{AL}-\mathrm{K}=70.2 \mathrm{~g} \mathrm{~kg}^{-1}$. From this, it can be calculated that the $\mathrm{P}_{2} \mathrm{O}_{5}: \mathrm{K}_{2} \mathrm{O}$ ratio is $1: 3.5$, which is not optimal for nutrition supply. Ash is primarily a $\mathrm{K}$ source and it is recommended to complete the $\mathrm{P}$ content with a $\mathrm{P}$ fertilizer to supply the appropriate ratio. Table 4 shows the changes in some soil properties after the experiment.

Comparing the $\mathrm{pH}_{\mathrm{H}_{2} \mathrm{O}}$ with $\mathrm{pH}_{\mathrm{KCl}}$ values it reveals that $\mathrm{pH}_{\mathrm{KCl}}$ indicate the changes in $\mathrm{pH}$ more sensitively, since it reflects the amount of $\mathrm{H}^{+}$-ions adsorbed on colloid surface as well. We observed the smallest $\mathrm{pH}$ at NPK treatment, due to the acidifying effect of ammoniumnitrate. The applied ash had an alkalizing effect, by $\mathrm{ASH} 2$ treatment the $\mathrm{pH}$ increased by almost one unit comparing to the control. Based on the AL-soluble K content of the ash we supposed at the beginning of the experiment that the ASH1 sample contained the same amount of available $\mathrm{K}$ as the NPK fertilizer dose. As the $\mathrm{AL}-\mathrm{K}$ and the $\mathrm{CaCl}_{2}-\mathrm{K}$ content were larger by the ASH1 treatment than by the NPK treatment it follows that the available $\mathrm{K}$ content for the ash sample was larger than that can be dissolved by the AL extractant.
Thus it is better to give the available $\mathrm{K}$ amount of the ash from the $\mathrm{HNO}_{3}$ digestion. The AL-K values of the soils were $2-3$ folds higher than the $\mathrm{CaCl}_{2}-\mathrm{K}$ values. Both extractants show that ash was a good $\mathrm{K}$ source. The AL-P values of the soils were 60-70 times higher than the $\mathrm{CaCl}_{2}-\mathrm{PO}_{4}{ }^{3-}-\mathrm{P}$ values as most of the $\mathrm{P}$ was in adsorbed form or in a precipitate. Each ash treatment increased the AL-P content of the soil more than the NPK treatment, thus the added ash was a significant $\mathrm{P}$ source. The $\mathrm{CaCl}_{2}-\mathrm{PO}_{4}{ }^{3-}-\mathrm{P}$ content that reflects to the readily available $\mathrm{P}$ form was the largest by the NPK treatment. The applied $\mathrm{Ca}\left(\mathrm{H}_{2} \mathrm{PO}_{4}\right)_{2}$ is water soluble, while in crop ashes the water solubility of $\mathrm{P}$ is usually lower than 1\% (Eichler-Löbermann et al., 2008).

From $\mathrm{CaCl}_{2}-\mathrm{Mn}$ values it can be observed that by ASH2 treatment the available Mn content of the soil was significantly decreased due to the alkalizing effect of ash. The $\mathrm{CaCl}_{2}-\mathrm{Mg}$ contents of the soil increased significantly as a result of ash treatments. Figure 1 shows the effect of the treatments on the dry matter production of ryegrass.

Significant increase was observed only by the ASH2 and ASH1+NP treatments. Preliminary we expected from NPK treatment to give as much increase as ASH1+NP treatment as the soluble NPK content of the two treatments were equal. Probably the acidifying effect of the treatment inhibited the growth of the plant. Among the treatments ASH1+NP treatment had the best effect on yield. The ASH1 dose can be converted as $4.2 \mathrm{t}$ ash hectare ${ }^{-1}$. The yield increasing effect of ASH1 and ASH2 treatments was approximately the same. Though the $\mathrm{P}$ dose by ASH2 treatment is more optimal than by ASH1 treatment, the $\mathrm{K}$ dose of this treatment is too high $\left(707 \mathrm{~kg} \mathrm{~K}_{2} \mathrm{O} \mathrm{ha}{ }^{-1}\right)$. This would cause the shift of optimal nutrient ratio, and increased leaching of K. Our result is in accordance with that of Füzesi et al. (2015).

Table 4.

Effect of fertilizer treatments on soil parameters

\begin{tabular}{|c|c|c|c|c|c|c|c|c|}
\hline Fert. & $\begin{array}{c}\mathrm{pH} \\
\mathrm{H}_{2} \mathrm{O}\end{array}$ & $\begin{array}{r}\mathrm{pH} \\
\mathrm{KCl}\end{array}$ & $\begin{array}{c}\mathrm{AL}-\mathrm{K} \\
\left(\mathrm{mg} \mathrm{kg}^{-1}\right)\end{array}$ & $\begin{array}{c}\text { AL-P } \\
\left(\mathrm{mg} \mathrm{kg}^{-1}\right)\end{array}$ & $\begin{array}{l}\mathrm{CaCl}_{2}-\mathrm{K} \\
\left(\mathrm{mg} \mathrm{kg}^{-1}\right)\end{array}$ & $\begin{array}{c}\mathrm{CaCl}_{2}-\mathrm{PO}_{4}{ }^{3-}-\mathrm{P} \\
\left(\mathrm{mg} \mathrm{kg}^{-1}\right)\end{array}$ & $\begin{array}{c}\mathrm{CaCl}_{2}-\mathrm{Mg} \\
\left(\mathrm{mg} \mathrm{kg}^{-1}\right)\end{array}$ & $\begin{array}{c}\mathrm{CaCl}_{2}-\mathrm{Mn} \\
\left(\mathrm{mg} \mathrm{kg}^{-1}\right)\end{array}$ \\
\hline $\mathrm{CON}$ & $5.9 \mathrm{a}$ & $4.9 \mathrm{ab}$ & $109.6 \mathrm{a}$ & $21.0 \mathrm{a}$ & $44.7 \mathrm{a}$ & $0.32 \mathrm{a}$ & $246.8 \mathrm{a}$ & $33.7 b$ \\
\hline NPK & $5.9 \mathrm{a}$ & $4.8 \mathrm{a}$ & $132.5 \mathrm{~b}$ & $30.7 b$ & $60.3 \mathrm{~b}$ & $0.80 \mathrm{~b}$ & $256.4 \mathrm{ab}$ & $42.9 \mathrm{c}$ \\
\hline ASH1 & $6.1 \mathrm{a}$ & $5.2 b$ & $161.4 \mathrm{c}$ & $32.9 \mathrm{bc}$ & $64.9 \mathrm{~b}$ & $0.50 \mathrm{ab}$ & $268.3 b c$ & $27.0 \mathrm{~b}$ \\
\hline ASH2 & $6.5 b$ & $5.8 \mathrm{c}$ & $234.3 \mathrm{~d}$ & $51.6 \mathrm{~d}$ & $110.6 \mathrm{c}$ & $0.55 b$ & $277.5 \mathrm{c}$ & $13.7 \mathrm{a}$ \\
\hline $\mathrm{ASH} 1+\mathrm{NP}$ & $6.1 \mathrm{a}$ & $5.1 \mathrm{~b}$ & $148.0 \mathrm{bc}$ & $38.2 \mathrm{c}$ & $60.7 b$ & $0.53 \mathrm{ab}$ & $265.5 b c$ & $29.0 \mathrm{~b}$ \\
\hline
\end{tabular}


Figure 1: Effect of fertilizer treatments on the yield of ryegrass

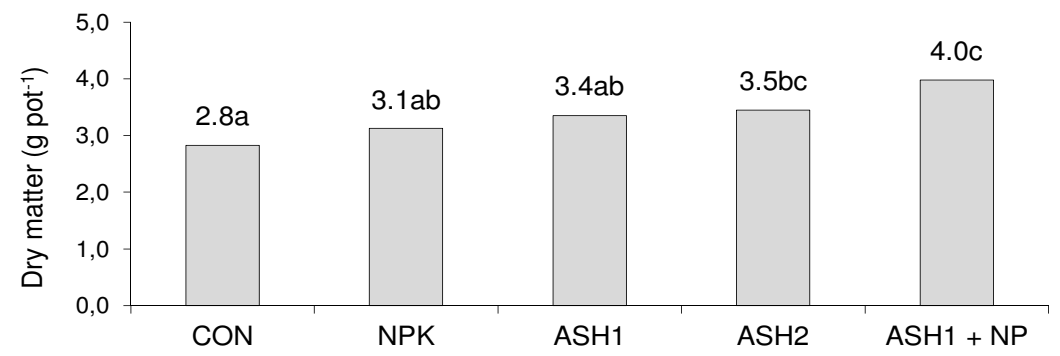

They set a small plot experiment, where they fertilized ryegrass and white mustard with wood ash in $1,2.5,5,10 \mathrm{tha}^{-1}$ dose in an acidic $\left(\mathrm{pH}_{\mathrm{KCl}}=5.6\right)$ loam soil. They stated that the optimum ash dose is up to $5 \mathrm{t} \mathrm{ha}^{-1}$, over these doses the $\mathrm{AL}-\mathrm{K}_{2} \mathrm{O}$ values exceed the optimum value. Tolner et al 2016 fertilized ryegrass with wood ash up to $60 \mathrm{t} \mathrm{ha}^{-1}$ dose in a pot experiment in a slightly acid loose sandy soil $\left(\mathrm{pH}_{\mathrm{KCl}}=5.26\right)$. They observed that up to $16,5 \mathrm{t} \mathrm{ha}^{-1}$ dose the yield was increased.

Table 5 represents the element content and uptake of plants respecting to $\mathrm{K}, \mathrm{P}, \mathrm{Ca}, \mathrm{Mg}, \mathrm{Zn}, \mathrm{Mn}$ and $\mathrm{Cu}$. In accordance with the soil soluble nutrient content the plant nutrient uptake also demonstrates that ash was a good K and P source. By ASH1 treatment the main K uptake increased up to $55 \%$ whereas $P$ uptake up to $46 \%$ in comparison to control. The largest element uptake was achieved in case of ASH1+NP treatment, which can be explained by the large yield. Though the ash sample contained plenty of $\mathrm{Ca}$ and $\mathrm{Mg}$ the $\mathrm{Ca}$ and $\mathrm{Mg}$ uptake of the plants were not raised compared to the control. For the studied microelements the tendencies in element content and uptake were different. For Mn even the ASH1 treatment decreased the Mn content and uptake of plant, and the application of larger dose by ASH2 treatment caused further decline in Mn utilization. These results are paralellel to the that we got for the soil soluble $\mathrm{CaCl}_{2}-\mathrm{Mn}$ content. The ash samples increased the soil $\mathrm{pH}$, which reduced $\mathrm{Mn}$ availability in spite of the fact that ash also contained Mn. The $\mathrm{Zn}$ content and uptake of plants did not change significantly by the ash treatments compared to the control. In case of $\mathrm{Cu}$ both the element contents and the uptake increased. By the utilization of $\mathrm{Cu}$ the $\mathrm{pH}$ increase did not inhibit the element uptake. The NPK fertilization increased the $\mathrm{Zn}, \mathrm{Mn}, \mathrm{Cu}$ content of the plants, which is associated with the acidifying effect of that treatment.

Table 5.

Effect of fertilizer treatments on the element content and uptake of plants

\begin{tabular}{|c|c|c|c|c|c|c|c|c|}
\hline & \multirow{2}{*}{ Fert. } & \multicolumn{7}{|c|}{ Nutrient content } \\
\hline & & $\mathrm{K}(\%)$ & $\mathrm{P}(\%)$ & $\mathrm{Ca}(\%)$ & $\operatorname{Mg}(\%)$ & $\mathrm{Zn}\left(\mathrm{mg} \mathrm{kg}^{-1}\right)$ & $\operatorname{Mn}\left(\mathrm{mg} \mathrm{kg}^{-1}\right)$ & $\mathrm{Cu}\left(\mathrm{mg} \mathrm{kg}^{-1}\right)$ \\
\hline $\mathrm{CON}$ & & $2.7 \mathrm{a}$ & $0.15 \mathrm{a}$ & $0.86 \mathrm{~cd}$ & $0.40 \mathrm{~d}$ & $58.2 \mathrm{a}$ & $170.9 \mathrm{c}$ & $9.6 \mathrm{a}$ \\
\hline NPK & & $3.2 \mathrm{ab}$ & $0.25 \mathrm{~d}$ & $0.86 \mathrm{~d}$ & $0.38 \mathrm{~cd}$ & $75.7 \mathrm{a}$ & $257.1 \mathrm{~d}$ & $10 \mathrm{ab}$ \\
\hline ASH1 & & $3.6 b c$ & $0.18 b$ & $0.68 \mathrm{ab}$ & $0.35 \mathrm{ab}$ & $58.4 \mathrm{a}$ & $116.8 \mathrm{ab}$ & $10.4 b c$ \\
\hline $\mathrm{ASH} 2$ & & $4.3 \mathrm{c}$ & $0.21 \mathrm{c}$ & $0.62 \mathrm{a}$ & $0.33 \mathrm{ab}$ & $44.3 \mathrm{a}$ & $80.8 \mathrm{a}$ & $10.4 \mathrm{bc}$ \\
\hline $\mathrm{ASH} 1+\mathrm{NP}$ & & $3.7 \mathrm{bc}$ & $0.22 \mathrm{c}$ & $0.75 b c$ & $0.37 \mathrm{bc}$ & $55.7 \mathrm{a}$ & $140.0 \mathrm{bc}$ & $11 \mathrm{c}$ \\
\hline & \multirow{2}{*}{ Fert. } & \multicolumn{7}{|c|}{ Nutrient uptake } \\
\hline & & $\mathrm{K}\left(\mathrm{mg} \operatorname{pot}^{-1}\right)$ & $\mathrm{P}\left(\mathrm{mg} \operatorname{pot}^{-1}\right)$ & $\mathrm{Ca}\left(\mathrm{mg} \mathrm{pot}^{-1}\right)$ & $\operatorname{Mg}\left(\mathrm{mg} \mathrm{pot}^{-1}\right)$ & $\mathrm{Zn}\left(\mathrm{mg} \mathrm{pot}^{-1}\right)$ & $\operatorname{Mn}\left(m g \operatorname{pot}^{-1}\right)$ & $\mathrm{Cu}\left(\mathrm{mg} \mathrm{pot}^{-1}\right)$ \\
\hline $\mathrm{CON}$ & & $78.1 \mathrm{a}$ & $4.1 \mathrm{a}$ & $24.2 \mathrm{ab}$ & $11.2 \mathrm{a}$ & $0.17 \mathrm{a}$ & $0.47 b c$ & $27.2 \mathrm{a}$ \\
\hline NPK & & $99.6 \mathrm{ab}$ & $7.6 \mathrm{~cd}$ & $27.0 \mathrm{ab}$ & $11.9 \mathrm{a}$ & $0.24 \mathrm{a}$ & $0.81 \mathrm{~d}$ & $31.3 \mathrm{ab}$ \\
\hline ASH1 & & $121.4 \mathrm{bc}$ & $6.0 \mathrm{~b}$ & $22.6 a$ & $11.8 \mathrm{a}$ & $0.20 \mathrm{a}$ & $0.39 \mathrm{ab}$ & $34.7 \mathrm{~b}$ \\
\hline ASH2 & & $148.2 \mathrm{c}$ & $7.2 \mathrm{c}$ & $21.5 \mathrm{a}$ & $11.5 \mathrm{a}$ & $0.15 \mathrm{a}$ & $0.28 \mathrm{a}$ & $36.0 \mathrm{~b}$ \\
\hline $\mathrm{ASH} 1+\mathrm{NP}$ & & $148.8 \mathrm{c}$ & $8.7 \mathrm{~d}$ & $29.7 b$ & $14.6 \mathrm{~b}$ & $0.22 \mathrm{a}$ & $0.56 \mathrm{~d}$ & $43.8 \mathrm{c}$ \\
\hline
\end{tabular}

\section{CONCLUSIONS}

Based on the analysis of the wheat straw ash sample and the pot experiment we conclude that wheat straw ash is suitable for the fertilization of the studied soil. Primarily wheat straw ash is a $\mathrm{K}$ source, but its $\mathrm{P}$ content is also significant. In order to reach optimal yield, ash should be completed with $\mathrm{N}$ and $\mathrm{P}$. Among the treatments ASH1+NP treatment had the best effect on yield. According to it $4.2 \mathrm{t} \mathrm{ha}^{-1}$ ash can be recommended, though further field trials are needed to confirm our result. Ash doses over $4.2 \mathrm{tha}^{-1}$ would pose an excessive $\mathrm{K}$ input, which can cause the shift of the optimal nutrient ratio. As ash increases soil $\mathrm{pH}$ its application can be recommended only in case of acidic soils. If we apply ash as fertilizer it is advisable to check the $\mathrm{pH}$ changes of the soil at the end of the growing seasons.

\section{ACKNOWLEDGEMENTS}

This study was supported by Hungarian-Ukrainian Intergovernmental S\&T Cooperation Programme for 2009-2010" R\&D bilateral project "Change of soils ecological characteristics of Ukraine and Hungary in the conditions of anthropogenic transformed ecosystems and optimization of biological processes of plants primary feed elements mobilization." 


\section{REFERENCES}

50/2001 (2001): Hungarian Government Regulation for the maximum allowed quantity of harmful metals that can be spread with wastewater, sewage sludge or sewage sludge compost on agricultural area.

Árendás, T.-Csathó, P.-Fodor, N.-Horváth, J. (2005): The nutrient turnover of Hungarian agriculture between 1901 and 2003 (In Hungarian). MTA Talajtani és Agrokémiai Kutatóintézet. Budapest. 17-23.

Buzás I. et al. (1979): Ca, Mg and micronutrients fertilization guidelines. [In: Buzás I. et al. (eds.) Fertilization guidelines and calculation methods.] MÉM NAK. Budapest. 48-60.

Eichler-Löbermann, B.-Schiemenz, K.-Makadi, M. (2008): Nutrient cycling by using residues of bioenergy production II. Effects of biomass ashes on plant and soil parameters. Cereal Res. Commun. 36: 1259-1262.

Füzesi, I.-Heil, B.-Kovács, G. (2015): Effects of Wood Ash on the Chemical Properties of Soil and Crop Vitality in Small Plot Experiments. Acta Silvatica et Lignaria Hungarica. 11: 55-64.

Houba, V. J. G.-Novozamsky, L.-Lexmond, T. M.-Van der Lee, J. J. (1990): Applicability of $0.01 \mathrm{M} \mathrm{CaCl} 2$ as a single extraction solution for the assessment of the nutrient status of soils and other diagnostic purposes. Commun. Soil Sci. Plant Anal. 21: 2281-2290.

lvarsson, E.-Nilsson, C. (1988): Smelting Temperatures of Straw Ashes With and Without Additives. Laboratory tests and computer analysis: Special report. Department of farm buildings, Swedish University of Agricultural Sciences, Lund. (in Swedish with English summary) 153: 36.

Mengel, K.-Kirkby, E. A. (1987): Principles of plant nutririon. P.O. Box CH-3048 Worblaufen - Bern/Schwitzerland International Potash Institute. 20.

MSZ 20135 (1999): Hungarian Standard: The determination of soluble nutrient content of soil.

MSZ 21470-50:1998 (1998): Hungarian Standard: Environmental soil analyis determination of the total and soluble amount of toxic elements and heavy metals.
Ochecova, P.-Tlustos, P. J.-Szakova, J. (2013): Effect of Cadmium in Wood Ash on Spring Wheat Vitality: pot experiment E3S Web of Conferences.

Röser, D.-Asikainen, A.-Raulund-Rasmussen, K.-Stupak, I. (eds.) (2008): Sustainable use of forest biomass for energy a synthesis with focus on the Baltic and Nordic region. 169

Rotheneder, E.-Handler, F.-Holzner, H. (2005): Assessment of the utilisation of differently processed Wood-Ashes as fertiliser in Agriculture and Forestry; Proceedings of „Bioenergy 2005” International Bioenergy in Wood Industry Conference and Exhibition. 12-15 September 2005. Finland. 445-449.

Safdar, M. N.-Naseem, K.-Amjad, M.-Mumtaz, A.-Raza, S (2009): Physiochemical quality assessment of wheat grown in different regions of Punjab. Pak. J. Agri. Res. 22. 1-2: 18-23.

Sander, M. L.-Andre'n, O. (1997): Ash from cereal and rape straw used for heat production: liming effect and contents of plant nutrients and heavy metals. Water Air Soil Pollut. 93: 93-108.

Schiemenz, K.-Eichler-Löbermann, B. (2010): Biomass ashes and their phosphorus fertilizing effect on different crops. Nutrient Cycling in Agroecosystems. 87. 3: 471-482.

Stankowski, S.-Maciorowski, R.-Gibczyńska, M. (2012): The biomass ash. Waste or useful by-product? Proceedings of the IV. Scientific and Practical Workshop - Ashes from TPPs: removal, transport, processing, landfilling. Moscow. April 19-20, 2012. 200-203.

Thamm, F.-né-Krámer , M.-Sarkadi, J. (1968): Determination of the phosphorus content of plants and fertilizers with ammoniumvanadate method. Agrokémia és Talajtan. 17: 145-156.

Tolner, L.-Ziegler, I.-Füleky, Gy.-Gulyás, M.-Rétháti, G. (2016) Stimulant and toxic effect of biomass ash dosage in pot experiment. Növénytermelés. Suppl. 65: 43-46.

Yasin, M.-Bhutto, A. W.-Bazmi, A. A.-Karim, S. (2010): Efficient utilization of rice-wheat straw to produce value added composite products. Int. J. Chem. Env. Eng. 1. 2: 136-143. 
